\title{
ANALISIS NILAI-NILAI BUDAYA KARIA DAN IMPLEMENTASINYA DALAM LAYANAN BIMBINGAN DAN KONSELING
}

\author{
Suriata \\ Bimbingan dan Konseling, Universitas Borneo Tarakan \\ email: suriata_nishahoky@yahoo.com
}

\begin{abstract}
The study aimed at discovering (1) the analysis on the values of Karia's culture, (2) the implication of Karia's culture in guidance and counseling service. The study was a qualitative approach with a case study. Data were analyzed using descriptive data analysis and observation analysis. The subjects of the study were prominent people, teenagers who will conduct Karia's culture, teenagers who have conducted karia's culture, and experts of guidance and counseling. The results of the study revealed that (1) five main values of Karia's culture were kafoluku (self understanding and behavior), kabhansule (understanding of role), kalempagi (growth and development), kafosampu (faith and independence), katandano wite (humble and trusteeship), linda (self existence); (2) the implication of values of Karia's culture in guidance and counseling service was indicated in basic service of family guidance.
\end{abstract}

Keyword: Values of karia's culture, guidance counseling.

Abstrak: Tujuan penelitian ini adalah untuk mengetahui (1) gambaran nilai-nilai budaya karia. (2) Implikasi budaya karia dalam layanan bimbingan dan konseling. Teknik analisis data dalam penelitian ini adalah analisis data deskriptif, dan analisis observasi. Subjek penelitian ini yaitu tokoh adat, remaja yang akan melaksanakan budaya karia, remaja yang telah melaksanakan karia, dan ahli Bimbingan dan Konseling. Hasil penelitian ini mengemukakan (1) lima nilai utama budaya karia yang diuraikan ke dalam prosesi budaya karia antara lain: kafoluku (pemahaman diri dan tingkah laku), kabhansule (pemahaman peran), kalempagi (pertumbuhan dan perkembangan), katandano wite (rendah hati dan amanah), dan linda (aktualisasi diri). (2) Implikasi nilai-nilai budaya karia dalam layanan bimbingan dan konseling dalam penelitian ini teridentifikasi dalam bentuk layanan dasar bidang bimbingan keluarga.

Kata kunci: Nilai budaya karia, bimbingan konseling.

\section{PENDAHULUAN}

Semua kebutuhan, kepercayaan, emosi, dan ekspektasi manusia dipengaruhi oleh budaya di mana mereka tinggal. Negara kita Indonesia adalah negara kultural yang ditempati oleh masyarakat yang memiliki bermacam-macam kebudayaan. Kita selaku bangsa dan rakyat Indonesia seharusnya sadar akan pentingnya bentuk suatu kebudayaan. Bukan hanya memahami, akan tetapi mulai dari sekarang mencoba untuk tetap melestarikan kebudayaankebudayaan yang ada.

Budaya atau yang dikenal dengan kata kebudayaan berasal dari bahasa Sansekertta yaitu kata buddhayah. Kata buddhayah adalah bentuk jamak dari kata buddhi yang berarti sebagai hal yang berkaitan dengan budi atau akal manusia. Sedangkan dalam bahasa Inggris, kebudayaan disebut dengan culture, kata culture sendiri berasal dari kata latin colere yang berarti pemeliharaan, mengelola dan penggarapan tanah menjadi tanah pertanian (Mulyadi, 1999: 20).

Kebudayaan dipandang dari sudut manusia individual merupakan suatu pengetahuan, suatu hasil ciptaan dari generasi dahulu, suatu pilihan yaitu kesanggupan untuk menentukan secara tepat sikap dirinya sendiri terhadap aksi dari lingkungannya, dan merupakan penghubung 
nilai-nilai dari generasi dahulu ke pihak generasi yang sedang tumbuh.

Menurut Daoed Joesoef (Salam, 2002: 116) :

Kebudayaan kiranya dapat diartikan sebagai segenap perwujudan dan keseluruhan hasil pikiran (logika), kemauan (etika), serta perasaan (estetika) manusia dalam rangka perkembangan kepribadian manusia, perkembangan hubungan manusia dengan manusia, hubungan manusia dengan alam, dan hubungan manusia dengan Tuhan Yang Maha Esa.

Salah satu tradisi yang diwariskan yaitu budaya karia yang berasal dari Propinsi Sulawesi Tenggara. Sebagai propinsi kepulauan, Sulawesi Tenggara terdiri dari empat etnis asli yaitu Muna, Tolaki, Buton, dan Morenene. Budaya karia sendiri merupakan tradisi pingitan bagi anak perempuan yang berasal dari etnis Muna. Dalam adat suku Muna, setiap anak perempuan yang akan memasuki usia remaja diwajibkan untuk menjalani tradisi pingitan (Karia) selama empat hari empat malam, dua hari dua malam, atau sehari semalam tergantung kesepakatan antara penyelenggara karia dengan tetua adat (pomantoto), atau disesuaikan dengan tingkat sosial atau kasta dalam masyarakat Muna.

Menjadi tanggung jawab bagi setiap orang tua di Muna untuk mendidik anak perempuan mereka dengan pengetahuan dasar sebelum memasuki masa dewasa dan kehidupan berumah tangga. Seperti dalam sebuah ungkapan filosofi orang tua Muna "kadekiho polambu, ane paeho omandehao kofatawalahae ghabu" yang berarti jangan engkau menikah, sebelum engkau memahami empat penjuru/sisi dapur. Ungkapan ini memberikan penegasan betapa pentingnya memberikan pengetahuan dasar sebagai bekal anak sebelum menjadi perempuan dewasa yang siap berumah tangga.

Budaya karia tidak hanya terbatas pada proses dan konsep urutan-urutan pelaksanaannya, tetapi yang paling penting adalah bagaimana pemahaman dan pendalaman nilainilai dari setiap sesi kegiatan dan simbol-simbol yang ada di dalamnya. Tradisi karia bertujuan untuk membekali anak perempuan dengan nilainilai etika, moral, dan spiritual berkaitan dengan statusnya sebagai anak, calon ibu, istri, maupun posisinya sebagai bagian dari masyarakat yang telah memasuki masa dewasa.
Bimbingan yang diberikan dalam budaya karia memiliki tujuan yang sejalan dengan bimbingan dan konseling yaitu agar peserta didik dapat memahami diri termasuk potensi dan tugas perkembangannya, mampu memahami lingkungan, mengarahkan diri dan menyesuaikan diri terhadap norma yang berlaku dalam lembaga pendidikan, keluarga, dan masyarakat.

Secara umum sasaran dari bimbingan dan konseling adalah mengembangkan apa yang terdapat pada diri tiap-tiap individu secara optimal agar setiap individu bisa berguna bagi dirinya sendiri, lingkungannya, dan masyarakat pada umumnya. Secara lebih khusus sasaran pembinaan pribadi melalui layanan bimbingan dan konseling mencakup tahapan-tahapan pengembangan kemampuan-kemampuan: (1) pengungkapan, pengenalan, dan penerimaan diri, (2) pengenalan lingkungan, (3) pengambilan keputusan, (4) pengarahan diri, dan (5) perwujudan diri (Sukardi dan Kusmawati, 2008: 9).

Natawidjaja (Yusuf dan Nurihsan, 2008: 6) mengartikan bimbingan dan konseling sebagai suatu proses pemberian bantuan kepada individu yang dilakukan secara berkesinambungan, supaya individu dapat memahami dirinya, sehingga sanggup mengarahkan dirinya dan dapat bertindak secara wajar, sesuai dengan tuntutan dan keadaan lingkungan sekolah, keluarga, masyarakat, dan kehidupan pada umumnya. Bimbingan dan konseling membantu individu mencapai perkembangan diri secara optimal sebagai makhluk sosial.

Budaya karia yang terus dijalankan oleh masyarakat Muna hingga saat ini, belum mampu menghasilkan pemahaman nilai yang mendalam dari peserta karia dari tiap prosesi yang dilakukan. Dari hasil studi awal penulis, ditemukan fakta para remaja yang dikaria hanya sebatas melaksanakan ritual namun tidak memahami kandungan filosofi dari kegiatan upacara adat karia. Hal ini berbuah menjadi sebuah kekhawatiran bagi kalangan orang tua di Muna, apalagi terpaan transformasi dan globalisasi yang dapat mengubah karakter hidup remaja yang perlahan-lahan meninggalkan nilainilai moral budayanya.

Budaya karia sebagai salah satu wujud jati diri budaya masyarakat Muna memiliki peran penting dan relevan dengan upaya pembentukan karakter. Nilai-nilai budaya karia mengandung proses bimbingan bagi kaum perempuan dalam 
hal pembinaan watak, karakter, dan pemahaman diri. Secara umum tujuan pelaksanaan budaya karia sejalan dengan sasaran bimbingan dan konseling yaitu untuk mengenal, memahami dan mengembangkan diri tiap individu secara optimal sehingga mampu bermanfaat bagi dirinya sendiri, masyarakat, dan lingkungannya. Hal tersebut menjadikan peneliti tertarik untuk menganalisis nilai-nilai budaya karia yang dijalankan oleh masyarakat Muna dan selanjutnya mengkaji lebih mendalam implikasi nilai-nilai budaya karia tersebut dalam layanan bimbingan dan konseling. Adapun yang menjadi tujuan penelitian ini yaitu untuk mengetahui gambaran nilai-nilai budaya karia dan memahami implikasi budaya karia dalam layanan bimbingan dan konseling.

Karia dalam pengertian "kari" yang artinya sikat/alat pembersih mengandung pengertian secara filosofi yaitu merupakan proses pembersihan diri seorang perempuan menjelang dewasa atau peralihan dari remaja ke dewasa. Proses ini dilakukan dengan harapan bahwa seorang wanita ketika telah disyarati dengan ritual karia maka dianggap lengkaplah proses pembersihan diri secara hakiki. Kepercayaan masyarakat Muna bahwa upacara ritual karia menjadi kewajiban bagi setiap orang tua yang memiliki anak perempuan. Karena itu proses pembersihan diri melalui ritual karia menjadi tanggung jawab orang tua.

Berdasarkan filosofi adat Muna bahwa ritual karia sebagai proses pembersihan diri dengan harapan bahwa anak perempuan yang menjelang dewasa telah disiapkan dari sejak dini sebagai tempat persemaian rahasia (benih-benih keturunan) dari laki-laki untuk mendapatkan keturunan yang saleh dan salehah. Konsep ini terkait dengan pendidikan seumur hidup (long life education). Ternyata di Muna telah diaplikasikan dalam kehidupan keluarga melalui ritual karia. Hal ini dapat teramati dalam proses upacara karia bahwa pelaksanaannya bukan hanya sekedar upacara ritual, tetapi merupakan proses pembinaan mental, moral agama, dan perilaku agar kelak memperoleh benih-benih keturunan yang berakhlak mulia. Hal ini sesuai dengan pemahaman orang tua di Muna bahwa, mendidik anak harus dilakukan sebelum anak itu lahir bahkan sebelum roh kedua orang tuanya hidup bersatu dalam satu rumah tangga. Ritual karia disamping sebagai proses pembersihan diri, juga merupakan bagian dari pendidikan kaum perempuan dalam menghadapi bahtera kehidupan berkeluarga.

Prosesi pelaksanaan karia terdiri dari 8 prosesi yakni: a) Kafoluku yaitu peserta dimasukkan dalam tempat yang telah dikemas khusus tempat karia yang disebut suo khusus bagi putri-putri raja dan songi untuk golongan masyarakat umum. Tahapan ini merupakan analogis bahwa manusia berada di alam arwah yaitu tempat gelap gulita hanya Tuhan yang dapat mengetahuinya. b) Proses Kabhansule yaitu proses perubahan posisi yang dipingit. Awalnya posisi kepala sebelah barat dengan baring menindis kanan selanjutnya posisinya dibalik kepala ke arah timur, kedua tangan di bawah kepala tindis kiri. Kondisi ini diibaratkan pada posisi bayi yang masih berada dalam kandungan yang senantiasa bergerak dan berpindah arah atau posisi. c) Proses Kalempagi diawali dengan proses debhalengka yaitu membuka pintu kaghombo (pingitan). Secara filosofi kalempagi berarti pelampauan atau melewati yaitu proses peralihan dari remaja ke usia dewasa. Oleh karena itu menurut tradisi di Muna bahwa yang dikaria harus usia remaja yang menjelang dewasa. d) Kafosampu (Pemindahan peserta karia dari rumah ke panggung) Pada hari keempat menjelang maghrib, para gadis pingitan siap dikeluarkan dari rumah atau ruang pingitan ke tempat tertentu yang disebut bhawono koruma (panggung). Pada waktu mereka diantar ke panggung tidak boleh menginjak atau menyentuh tanah. Gadis-gadis yang mendampingi peserta karia harus yang masih hidup kedua orang tuanya. Mereka bertugas memegang sulutaru, yaitu semacam pohon terang yang terbuat dari kertas warnawarni dan di puncaknya dipasangkan lilin yang menyala. Pengertian lain dari sulutaru adalah merupakan isyarat, harapan dari peserta karia agar ke depan memperoleh jalan hidup yang lebih cerah. Oleh karena itu, nyala lilin di puncak sulutaru menjadi simbol masa depannya. e) Proses Katandano Wite adalah langkah keempat dalam proses karia. Katandano wite yaitu sentuhan tanah pada ubun-ubun, dahi, dan selanjutnya seluruh persendian hingga pada telapak kaki para peserta karia dengan etika sebagai berikut:

Pegawai sarah mengambil tanah dari tempat yang telah disediakan (piring putih) 
kemudian melakukan proses katandano wite (sentuhan tanah) dari ubun-ubun turun ke dahi dengan menggambarkan huruf alif. Setelah katandano wite selesai maka proses selanjutnya adalah pembacaan doa selamat sebagai tanda syukur bahwa segala kegiatan telah selesai dan mendoakan agar peserta karia, seluruh keluarga, dan seluruh yang hadir di acara tersebut dapat menjalani kehidupan yang penuh berkah dan tanggung jawab. f) Linda Setelah rangkaian acara selesai maka pomantoto atau pemandu melakukan tari linda sebagai pendahuluan yang kemudian disusul oleh peserta karia secara berurutan yang dimulai dari putri tuan rumah dan seterusnya disusul oleh peserta yang lain secara bergiliran berdasarkan urutan duduknya. Pemaknaan tari linda yang dipertunjukkan oleh peserta karia dapat dimaknai dalam beberapa aspek yaitu: (1) dari aspek estetika bahwa sebagai perempuan harus mampu menunjukkan kemampuan sesuatu yang indah dan berseni sebagai lambang keempuan wanita yang menggambarkan jiwanya yang halus; (2) dari aspek kejuangan bahwa perempuan yang dikaria telah mampu melampaui perjuangan melawan hawa nafsu dalam songi, sehingga sebagai simbol kegembiraan maka dilakonkan suatu tarian yaitu linda. ; (3) dari aspek pembentukan keluarga, bahwa dalam pertunjukkan tari linda yang dilakoni oleh peserta karia biasa terjadi sebagai langkah awal perkenalan antara laki-laki dan perempuan untuk kemudian saling jatuh cinta yang dipertalikan dengan kagholuno samba. g) Kahapui (Membersihkan) Esok harinya setelah acara kafosampu diadakanlah acara kahapui, yaitu acara ritual pemotongan pisang yang telah ditanam atau disiapkan di depan rumah penyelenggara acara karia. Pemaknaan pohon pisang dalam proses ini merupakan simbol bahwa kehidupan pisang yang silih berganti, bila dipotong satu maka akan tumbuh yang lain sebagai penggantinya. h) Kaghorono Bhansa sebagai penutup dari rangkaian acara upacara karia adalah kaghorono bhansa. Pada acara ini, bhansa/mayang pinang yang dipakai untuk memukul-mukulkan badan peserta karia dihanyutkan ke dalam sungai.

Filosofi dari acara ini adalah melepaskan segala etika buruk yang ada pada peserta karia. Tetapi oleh sebagian orang tua di Muna hal ini menjadi isyarat jodoh, nasib, dan takdir peserta karia. Misalnya, pada saat dilakukan kaghoro bhansa, kondisi mayang pinang ada yang tenggelam, terapung, dan ada pula yang hanyut terbawa air. Berdasarkan pemaknaan orang tua bahwa kondisi mayang pinang berkaitan dengan masa depan peserta karia baik jodoh maupun rezeki. Tetapi itu hanya sebatas praduga dan kebenarannya tidak dapat dipastikan (La Oba dkk, 2008).

Menurut Tolbert (Hikmawati, 2011: 1) bimbingan adalah seluruh program atau semua kegiatan dan layanan dalam lembaga pendidikan yang diarahkan pada membantu individu agar mereka dapat menyusun dan melaksanakan rencana serta melakukan penyesuaian diri dalam semua aspek kehidupannya sehari-hari. Bimbingan merupakan layanan khusus yang berbeda dengan bidang pendidikan lainnya.

Bimbingan menurut Prayitno (2004: 99) adalah proses pemberian bantuan yang dilakukan oleh orang yang ahli kepada seorang atau beberapa orang individu, baik anak-anak, remaja, maupun dewasa; agar orang yang dibimbing dapat mengembangkan kemampuan dirinya sendiri dan mandiri; dengan memanfaatkan kekuatan individu dan sarana yang ada dan dapat dikembangkan; berdasarkan norma-norma yang berlaku.

Tujuan umum bimbingan dan konseling adalah untuk membantu individu memperkembangkan diri secara optimal sesuai dengan tahap perkembangan dan predisposisi yang dimilikinya (seperti kemampuan dasar dan bakatbakatnya), berbagai latar belakang yang ada (seperti latar belakang keluarga, pendidikan, status sosial ekonomi), serta sesuai dengan tuntutan positif lingkungannya. Dalam kaitan ini, bimbingan dan konseling membantu individu untuk menjadi insan yang berguna dalam kehidupannya yang memiliki berbagai wawasan, pandangan, interpretasi, pilihan, penyesuaian, dan keterampilan yang tepat berkenaan dengan diri sendiri dan lingkungannya (Prayitno, 2004: 114).

Dilihat dari masalah individu, ada empat jenis bidang bimbingan yaitu: (1) bimbingan belajar, (2) bimbingan sosial pribadi, (3) bimbingan karir, dan (4) bimbingan keluarga.

Bimbingan belajar yaitu bimbingan yang diarahkan untuk membantu individu dalam menghadapi dan memecahkan masalah-masalah belajar. Yang tergolong masalah belajar yaitu pengenalan kurikulum, pemilihan jurusan atau konsentrasi, cara belajar, penyelesaian tugastugas dan latihan, pencarian dan penggunaan 
sumber belajar, perencanaan pendidikan lanjutan, dan lain-lain. Bimbingan belajar dilakukan dengan cara mengembangkan suasana belajarmengajar yang kondusif agar terhindar dari kesulitan belajar.

Bimbingan sosial-pribadi merupakan bimbingan untuk membantu para individu dalam memecahkan masalah-masalah sosial-pribadi. Bimbingan sosial-pribadi diarahkan untuk memantapkan kepribadian dan mengembangkan kemampuan individu dalam menangani masalahmasalah dirinya. Bimbingan ini merupakan layanan yang mengarah pada pencapaian pribadi yang seimbang dengan memperhatikan keunikan karakteristik pribadi serta ragam permasalahan yang dialami oleh individu.

Bimbingan karir yaitu bimbingan untuk membantu individu dalam perencanaan, pengembangan dan pemecahan masalah-masalah karir seperti: pemahaman terhadap jabatan dan tugas-tugas kerja, pemahaman kondisi dan kemampuan diri, pemahaman kondisi lingkungan, perencanaan dan pengembangan karir, penyesuaian pekerjaan, dan pemecahan masalahmasalah karir yang dihadapi. Bimbingan karir terkait dengan perkembangan kemampuan kognitif, afektif, maupun keterampilan individu dalam mewujudkan konsep diri yang positif, memahami proses pengambilan keputusan, maupun perolehan pengetahuan dalam keterampilan yang akan membantu dirinya memasuki sistem kehidupan sosial budaya yang terus menerus berubah.

Bimbingan keluarga merupakan upaya pemberian bantuan kepada individu sebagai pemimpin/anggota keluarga agar mereka mampu menciptakan keluarga yang utuh dan harmonis, memberdayakan diri secara produktif, dapat menciptakan dan menyesuaikan diri dengan norma keluarga, serta berpartisipasi aktif dalam mencapai kehidupan keluarga yang bahagia. Bimbingan perkembangan di lingkungan pendidikan merupakan pemberian bantuan kepada seluruh peserta didik yang dilakukan secara berkesinambungan, supaya mereka dapat memahami dirinya (potensi dan tugas-tugas perkembangannya), dan memahami lingkungannya sehingga mereka mampu mengarahkan diri, dan menyesuaikan diri secara dinamis dan konstruktif terhadap norma yang berlaku atau tuntutan lembaga pendidikan, keluarga, masyarakat, dan lingkungan kerja yang akan dimasukinya kelak (Yusuf dan Nurihsan, 2008: 10).

Pelayanan bimbingan dan konseling mempunyai lingkup yang cukup luas. Ditinjau dari segi pelayanan yang diberikan, layanan bimbingan dan konseling dapat mencakup layanan berikut: (1) Layanan orientasi, yaitu pelayanan bimbingan dan konseling yang memungkinkan peserta didik (konseli) memahami lingkungan yang baru dimasuki peserta didik, untuk mempermudah dan memperlancar berperannya peserta didik di lingkungan yang baru itu. (2) Layanan informasi, yaitu layanan bimbingan dan konseling yang memungkinkan peserta didik (konseli) menerima dan memahami berbagai informasi yang dapat dipergunakan sebagai bahan pertimbangan dan pengambilan keputusan untuk kepentingan peserta didik (konseli). (3) Layanan penempatan dan penyaluran, yaitu pelayanan bimbingan dan konseling yang memungkinkan peserta didik (konseli) memperoleh penempatan dan penyaluran yang tepat misalnya penempatan dan penyaluran di dalam kelas, kelompok belajar jurusan atau program studi, program pelatihan, magang, kegiatan kurikuler atau ekstrakurikuler sesuai dengan potensi, bakat dan minat, serta kondisi pribadinya. (4) Layanan pembelajaran, yaitu pelayanan bimbingan dan konseling yang memungkinkan peserta didik (konseli) mengembangkan diri berkenaan dengan sikap dan kebiasaan belajar yang baik, materi belajar yang cocok dengan kecepatan dan kesulitan belajarnya, serta berbagai aspek tujuan dan kegiatan belajar lainnya. (5) Layanan konseling perorangan, yaitu pelayanan bimbingan dan konseling yang memungkinkan peserta didik (konseli) mendapatkan pelayanan langsung tatap muka (secara perorangan) dengan guru pembimbing (konselor) dalam rangka pembahasan dan pengentasan permasalahan pribadi yang dideritanya. (6) Layanan bimbingan kelompok, yaitu pelayanan bimbingan dan konseling yang memungkinkan sejumlah peserta didik secara bersama-sama melalui dinamika kelompok memperoleh berbagai bahan dari narasumber tertentu (terutama dari guru pembimbing/konselor) dan atau membahas secara bersama-sama pokok bahasan (topik) tertentu yang berguna untuk menunjang pemahaman dan kehidupannya sehari-hari dan atau untuk perkembangan dirinya baik sebagai 
individu maupun sebagai pelajar, dan untuk pertimbangan dalam pengambilan keputusan. (7) Layanan konseling kelompok, yaitu pelayanan bimbingan dan konseling yang memungkinkan peserta didik (konseli) memperoleh kesempatan untuk pembahasan dan pengentasan permasalahan yang dialaminya melalui dinamika kelompok. (8) Aplikasi instrumentasi bimbingan dan konseling, yaitu kegiatan pendukung bimbingan dan konseling untuk mengumpulkan data dan keterangan tentang peserta didik (konseli), keterangan tentang lingkungan peserta didik dan "lingkungan yang lebih luas". Pengumpulan data ini dapat dilakukan dengan berbagai instrumen, baik tes maupun nontes. (9) Penyelenggaraan himpunan data, yaitu kegiatan pendukung bimbingan dan konseling untuk menghimpun seluruh data dan keterangan yang relevan dengan keperluan pengembangan peserta didik (konseli). (10) Konferensi kasus, yaitu kegiatan pendukung bimbingan dan konseling untuk membahas permasalahan yang dialami oleh peserta didik (konseli) dalam suatu forum pertemuan yang dihadiri oleh berbagai pihak yang diharapkan dapat memberikan bahan, keterangan, kemudahan dan komitmen bagi terentaskannya permasalahan tersebut. (11) Kunjungan rumah, yaitu kegiatan pendukung bimbingan dan konseling untuk memperoleh data, keterangan, kemudahan dan komitmen bagi terentaskannya permasalahan peserta didik (konseli) melalui kunjungan ke rumahnya. Kegiatan ini memerlukan kerja sama yang penuh dari orang tua dan anggota keluarga lainnya. (12) Alih tangan kasus yaitu, kegiatan pendukung bimbingan dan konseling untuk mendapatkan penanganan yang lebih tepat dan tuntas atas masalah yang dialami peserta didik (konseli) dengan memindahkan penanganan kasus dari satu pihak ke pihak lainnya. Kegiatan ini memerlukan kerja sama yang erat dan mantap antara berbagai pihak yang dapat memberikan bantuan atas penanganan masalah tersebut (Sukardi dan Kusmawati, 2008: 10).

\section{METODE}

Jenis penelitian yang digunakan dalam penelitian ini adalah penelitian deskriptif kualitatif yang bertujuan untuk memperoleh pemahaman dan penafsiran mendalam tentang nilai-nilai budaya karia serta implikasinya dalam layanan bimbingan dan konseling. Untuk memperoleh data yang dibutuhkan dalam penelitian ini, maka digunakan alat pengumpul data yang meliputi teknik wawancara mendalam, observasi, dan dokumentasi. Data yang terkumpul kemudian dianalisis dalam kegiatan yang meliputi reduksi data, display data dan mengambil kesimpulan dan verifikasi, prosedur analisis data. Teknik keabsahan data yang digunakan dalam penelitian ini yakni triangulasi. Untuk menguji keabsahan data yang telah diperoleh maka peneliti melakukan triangulasi metode dan triangulasi sumber sehingga data yang diperoleh memiliki tingkat kepercayaan yang tinggi berdasarkan fokus dan tujuan penelitian.

\section{HASIL DAN PEMBAHASAN}

Berdasarkan hasil penelitian dengan menggunakan pendekatan kualitatif menunjukkan bahwa nilai-nilai budaya karia yang terbagi dalam delapan prosesi, diantara prosesi tersebut yakni kafoluku, kabhansule, kalempagi, katandano wite, dan linda, hasil analisisnya merujuk pada satu layanan bimbingan dan konseling yaitu pada bidang bimbingan keluarga.

Seperti yang diungkapkan Yusuf dan Nurihsan (2008: 10) yang menjelaskan bahwa dilihat dari masalah individu, ada empat jenis bidang bimbingan dan konseling yaitu: (1) bimbingan belajar, (2) bimbingan sosial pribadi, (3) bimbingan karir, dan (4) bimbingan keluarga. Bimbingan keluarga sebagai salah satu bidang bimbingan dan konseling merupakan upaya pemberian bantuan kepada individu sebagai pemimpin/anggota keluarga agar mereka mampu menciptakan keluarga yang utuh dan harmonis, memberdayakan diri secara produktif, dapat menciptakan dan menyesuaikan diri dengan norma keluarga, serta berperan/berpartisipasi aktif dalam mencapai kehidupan keluarga yang bahagia.

Adapun hasil analisisnya dapat kita lihat pada tabel berikut:

Tabel 4.2. Prosesi dan Nilai Budaya Karia

\begin{tabular}{ccc}
\hline $\begin{array}{c}\text { Prosesi } \\
\text { Budaya } \\
\text { Karia }\end{array}$ & $\begin{array}{c}\text { Nilai-nilai yang } \\
\text { ditanamkan }\end{array}$ & $\begin{array}{c}\text { Bidang } \\
\text { Bimbingan } \\
\text { dan } \\
\text { Konseling }\end{array}$ \\
\hline 1. Kafoluku & Pengenalan diri & Keluarga \\
\hline
\end{tabular}




\begin{tabular}{lll}
\hline & (who am I) & \\
\hline 2. Kabhansu & $\begin{array}{l}\text { Pemahaman } \\
\text { peran }\end{array}$ & Keluarga \\
\hline 3. Kalempagi & Pemahaman diri & Keluarga \\
\hline $\begin{array}{l}\text { 4. Katandano } \\
\text { Wite }\end{array}$ & $\begin{array}{l}\text { Sifat rendah hati } \\
\text { dan amanah }\end{array}$ & Keluarga \\
\hline 5. Linda & Aktualisasi diri & Keluarga \\
\hline
\end{tabular}

Layanan bimbingan dan konseling diselenggarakan sebagai suatu totalitas yang menyangkut segenap potensi, kecenderungan, perkembangan, dinamika kehidupan, permasalahan, dan interaksi antara berbagai unsur yang ada. Chiskolm dalam Prayitno (2004: 94) mengungkapkan bahwa bimbingan membantu setiap individu untuk lebih mengenali berbagai informasi tentang dirinya sendiri. Bila tiap individu mampu mengenali dirinya, selanjutnya mereka diharapkan mampu melakukan sesuatu sesuai dengan kelebihan dan kekurangan yang dimiliki. Sebagaimana yang diungkapkan Walgito (2004: 10) bahwa: Manusia perlu mengenal dirinya sendiri agar dapat bertindak dengan tepat sesuai dengan kemampuan yang ada pada dirinya. Namun demikian, tidak semua manusia mampu mengenal segala kemampuan yang dimilikinya, dan bantuan ini dapat diberikan oleh bimbingan dan konseling.

Selain telah menjadi sebuah keharusan, setiap individu tentunya memiliki keinginan untuk mengenali berbagai informasi tentang diri sendiri. Namun hal ini tetap membutuhkan bantuan bimbingan dari orang lain yang lebih berpengalaman dan diwujudkan dalam suatu bentuk bimbingan. Bimbingan untuk mengenali diri seperti ini ternyata diwujudkan dalam nilai tahapan pertama budaya karia yaitu dalam prosesi kafoluku.

Kafoluku adalah proses pembinaan remaja perempuan dalam ruangan gelap yang disebut suo atau songi. Ruangan gelap tersebut menggambarkan rahim seorang ibu, jadi prosesi kafoluku seperti menggembalikan seorang anak dalam rahim ibunya. Nilai yang diharapkan yaitu remaja perempuan dapat mengenali asal atau tempat awal hidup mereka (dari rahim ibu), mengenali tanggung jawab seorang perempuan sebagai istri sekaligus ibu yang berujung pada adanya sebuah pengenalan diri. Jadi melalui bimbingan yang dikemas dalam prosesi kafoluku, individu dibantu untuk mengenali dirinya sehingga dapat bertindak sesuai dengan kemampuan yang dimiliki.

Individu yang dihadapi dalam bimbingan dan konseling adalah individu yang hidup dalam masyarakat. Karena itu, dalam memandang individu tidak pernah terlepas dari masyarakatnya beserta latar belakang sosial, dan kebudayaan. Hal ini menimbulkan adanya dinamika yang dapat memunculkan masalah bila tidak ada pemahaman dari individu tersebut. Untuk itulah bimbingan hadir membantu individu agar mampu memahami diri serta lingkungannya.

Shertzer dan Stone dalam Yusuf (2006: 29) mengungkapkan bahwa bimbingan sebagai proses pemberian bantuan kepada siswa agar mampu memahami diri dan lingkungannya. Bimbingan sebagai proses pemberian bantuan kepada siswa agar mampu memahami potensi diri dan lingkungannya, menerima diri, mengembangkan dirinya secara optimal, dan menyesuaikan diri secara positif dan konstruktif terhadap tuntutan norma kehidupan (agama dan budaya) sehingga mencapai kehidupan yang bermakna (berbahagia), baik secara personal maupun sosial. Selanjutnya Natawidjaja dalam Winkel dan Hastuti (2006: 29) mengungkapkan bahwa: Bimbingan adalah proses pemberian bantuan kepada individu yang dilakukan secara berkesinambungan, agar mampu memahami dirinya sehingga bisa mengarahkan diri dan dapat bertindak wajar, sesuai dengan tuntutan dan keadaan keluarga serta masyarakat.

Bimbingan untuk memahami diri serta memahami peran terwujud dalam prosesi budaya karia yaitu dalam prosesi kabhansule dan kalempagi. Kabhansule adalah penggambaran kehidupan seorang anak ketika berada dalam rahim ibunya dan nilai utama yang terkandung dalam prosesi ini adalah pemahaman peran seorang perempuan yang nantinya akan berperan sebagai ibu. Dalam prosesi kabhansule, terdapat langkah saling menyuapi yang dilakukan oleh dua pasang remaja dan hal ini menggambarkan kehidupan dua pasang suami istri yang mengawali kehidupan berumah tangga. Selanjutnya, kalempagi adalah sebagai pertanda seorang perempuan yang telah mengalami peralihan menjadi perempuan dewasa yang bertanggung jawab. Nilai utama yang terkandung dalam prosesi ini yaitu nilai pemahaman diri. 
Individu yang telah memiliki pemahaman diri maka secara tidak langsung akan paham akan perannya dalam keluarga, lembaga pendidikan dan masyarakat. Nilai prosesi kabhansule dan kalempagi memberikan wujud bimbingan yang membantu individu memahami diri sekaligus memahami perannya sehingga mampu mengarahkan diri, menghadapi tantangan atau kesulitan dan mengatasi suatu masalah yang berujung pada pencapaian kebahagiaan hidup.

Secara umum sasaran dari bimbingan adalah mengembangkan apa yang terdapat pada diri tiap-tiap individu secara optimal agar setiap individu bisa berguna bagi dirinya sendiri, lingkungannya, dan masyarakat pada umumnya. Hal ini sejalan dengan kebutuhan tiap manusia untuk mengembangkan diri dalam bentuk aktualisasi diri di lingkungannya. Untuk meningkatkan aktualisasi diri, berbagai potensi dan kondisi positif individu dalam rangka perkembangan dirinya harus terus terpelihara dan terkembangkan.

Boy dan Pine dalam Yusuf (2006: 35) mengungkapkan bahwa tujuan bimbingan adalah membantu siswa/individu menjadi lebih matang dan lebih mengaktualisasikan dirinya, membantu siswa/individu maju dengan cara positif, membantu dalam sosialisasi dengan memanfaatkan sumber-sumber dan potensinya sendiri. Persepsi dan wawasan individu berubah, maka timbullah reorientasi positif terhadap kepribadian dan kehidupannya.

Dalam budaya karia tepatnya pada prosesi tari linda, remaja perempuan melakukan tari linda sebagai sebuah ungkapan kegembiraan. Nilai utama dari prosesi ini yaitu diharapkan kepada mereka yang telah dikaria mampu mengembangkan potensi yang dimiliki dan berani untuk mengaktulisasikan diri dalam lingkungannya. Nilai ini tentunya memiliki implikasi yang jelas bagi sebuah layanan bimbingan dimana bimbingan yang dikemas dalam tari linda membantu individu menjadi lebih matang dan lebih mengaktualisasikan dirinya, membantu individu maju dengan cara positif, membantu dalam sosialisasi dengan memanfaatkan sumber-sumber dan potensinya sendiri.

Layanan bimbingan utamanya bimbingan keluarga sebagai upaya pemberian bantuan kepada individu agar mereka mampu menciptakan keluarga yang harmonis, memberdayakan diri secara produktif, serta berpartisipasi aktif mencapai kehidupan keluarga yang bahagia. Orientasi harapan masa depan dalam hal membina keluarga juga menjadi perhatian dalam layanan bimbingan. Seperti yang diungkapkan Sukardi dan Kusmawati (2008: 13) bahwa dalam bimbingan, individu dibantu untuk mengenal dan berhubungan dengan lingkungan sosialnya yang dilandasi budi pekerti luhur, tanggung jawab kemasyarakatan dan kenegaraan, dan salah satu pokoknya yakni orientasi tentang hidup berkeluarga.

Seperti yang kita ketahui, tak jarang individu terlibat banyak masalah yang diakibatkan oleh kelemahan-kelemahan diri seperti kepribadian yang sombong, egois, manja dan tidak mandiri, serta mudah putus asa. Dalam kondisi inilah, bimbingan hadir untuk mengatasi hal tersebut. Karena seperti pendapat Yusuf (2006: 44) bahwa seseorang dapat dikatakan telah berhasil bila mampu memecahkan masalah dengan baik, tidak mudah frustasi, putus asa, atau bersikap sabar dalam menghadapi suatu masalah. Suatu bimbingan diarahkan untuk memantapkan kepribadian dan mengembangkan kemampuan individu dalam menangani masalahmasalah dirinya.

Lebih lanjut, Prayitno dalam Sukardi dan Kusmawati (2008: 2) mengungkapkan bahwa bimbingan merupakan bantuan yang diberikan kepada seseorang (individu) atau sekelompok orang agar mereka itu dapat berkembang menjadi pribadi-pribadi yang mandiri. Kemandirian ini mencakup lima fungsi pokok yang hendaknya dijalankan oleh pribadi mandiri, yaitu: (a) mengenal diri sendiri dan lingkungannya, (b) menerima diri sendiri dan lingkungannya secara positif dan dinamis, (c) mengambil keputusan, (d) mengarahkan diri, dan (e) mewujudkan diri.

Secara khusus bimbingan dan konseling bertujuan untuk membantu siswa atau peserta didik agar dapat mencapai tugas-tugas perkembangan dalam hal keimanan kepada Tuhan Yang Maha Esa. Seperti yang diungkapkan Yusuf (2006: 41) bahwa tujuan bimbingan dan konseling yaitu (a) agar individu memiliki komitmen yang kuat dalam mengamalkan nilai-nilai keimanan dan ketaqwaan kepada Tuhan Yang Maha Esa, baik dalam kehidupan pribadi, keluarga, pergaulan dengan teman sebaya, sekolah, tempat kerja, maupun masyarakat pada umumnya, (b) memiliki sikap toleransi terhadap umat beragama lain, dengan saling menghormati dan memelihara 
hak dan kewajibannya masing-masing, (c) memiliki pemahaman tentang irama kehidupan yang bersifat fluktuatif antara yang menyenangkan (anugrah) dan yang tidak menyenangkan (musibah), dan mampu meresponnya secara positif sesuai dengan ajaran agama yang dianut.

Bimbingan hadir sebagai upaya untuk memantapkan pemahaman tentang kelemahan diri dan usaha-usaha penanggulangannya serta memantapkan kemampuan bertingkah laku dan berhubungan sosial baik di rumah, sekolah, maupun di masyarakat luas dengan menjunjung tinggi tata krama, sopan santun, serta nilai-nilai agama, adat, hukum, ilmu, dan kebiasaan yang berlaku (Sukardi dan Kusmawati, 2008: 12). Jadi bimbingan merupakan layanan yang mengarah pada pencapaian pribadi yang mantap, dengan memperhatikan keunikan karakteristik pribadi serta ragam permasalahan individu.

Pembentukan kepribadian yang lebih baik termasuk di dalamnya sifat rendah hati/tidak sombong dikemas dalam bimbingan budaya karia yakni pada prosesi katandano wite. Katandano wite adalah proses penyentuhan tanah pada anggota tubuh remaja peserta karia untuk mengingatkan asal keberadaannya dari tanah sehingga mereka menjadi pribadi yang rendah hati.

Nilai prosesi katandano wite memberikan wujud bimbingan yang membantu individu mampu memecahkan masalah dengan baik, rendah hati, memiliki kepribadian yang mantap dan mampu mengembangkan kemampuannya dalam menangani masalah-masalah dirinya. Selain itu, simbol yang muncul ketika prosesi katandano wite dilakukan yakni bagaimana peran seorang perempuan yang mampu bersikap amanah karena ia mengemban amanah untuk menjaga rahasia keluarga dan rumah tangganya.

Upacara karia merupakan evaluasi dari seluruh pakaian rohani bagi seorang perempuan karena setelah upacara karia maka perempuan tersebut dianggap telah bersih dan mapan. Setelah semua prosesi selesai, maka remaja perempuan yang telah disarati dengan ritual karia dianggap telah memahami seluk beluk kehidupan dunia khususnya yang berkaitan dengan kehidupan berumah tangga. Proses ini menjadi modal utama pembentukan keluarga sakinah, mawaddah, dan warrahmah. Adapun prototype Layanan Dasar Bimbingan Keluarga Berbasis Budaya Karia: (1)
Profesi Karia; Kafoloku, Kabhansule, Kalempagi, Katandano Wite, Linda dan. (2) Materi: Pemahaman diri dan tingkah laku, Pemahaman peran, Pertumbuhan dan perkembangan, Menjadi pribadi yang rendah hati, Eksistensi diri.

\section{SIMPULAN DAN SARAN}

Berdasarkan hasil penelitian dan pembahasan yang telah diuraikan sebelumnya, maka dapat disimpulkan sebagai berikut: Analisis nilai-nilai budaya karia dapat dijabarkan ke dalam delapan prosesi diantaranya yaitu kafoluku mengandung nilai pengenalan diri, kabhansule nilai pemahaman peran, kalempagi nilai pemahaman peran, katandano wite nilai kerendahan hati dan amanah, dan linda nilai aktualisasi diri.

Implikasi nilai-nilai budaya karia dalam layanan bimbingan dan konseling yaitu pada bimbingan keluarga dan dalam penelitian ini diuraikan dalam bentuk sebuah layanan dasar bimbingan dan konseling berbasis budaya karia.

Berdasarkan kesimpulan hasil penelitian, maka diajukan saran-saran sebagai berikut:

1) Bagi Remaja diharapkan dapat melestarikan kebudayaan daerahnya dan memahami nilai-nilai budaya yang dimiliki serta mampu mengaplikasikannya dalam kehidupan sehari-hari. 2) Bagi Orang tua diharapkan dapat menjadi contoh dan memberi pemahaman tentang nilai-nilai kebudayaan kepada anak-anaknya. 3) Bagi guru pembimbing diharapkan dapat mengembangkan layanan bimbingan konseling yang dapat membantu siswa/remaja memahami nilai nilai budaya khususnya budaya karia. 4) Bagi peneliti selanjutnya dapat menjadi baan informasi, referensi serta pengembangan penelitian selanjutnya tentang kebudayaan.

\section{DAFTAR RUJUKAN}

Abimanyu, Soli dan Manrihu, Thayeb. 2009. Teknik dan Laboratorium Konseling Jilid I. Makassar: Badan Penerbit UNM.

Hikmawati, Fenti. 2011. Bimbingan Konseling Edisi Revisi. Jakarta: Raja Grafindo Persada.

La Oba, dkk. 2008. Upacara Adat Karia (Pingitan) sebagai Tutura Masyarakat Muna. Raha: Sultra. 
Mulyadi, Yad. 1999. Pengantar Antropologi. Jakarta: Departemen Pendidikan dan Kebudayaan.

Prayitno dan Amti, Erman. 2004. Dasar-Dasar Bimbingan dan Konseling. Jakarta: Rineka Cipta.

Salam, Burhanuddin. 2002. Pengantar Pedagogik (Dasar-Dasar Ilmu Mendidik). Jakarta: Rineka Cipta.

Sukardi dan Kusmawati. 2008. Proses Bimbingan dan Konseling di Sekolah. Jakarta: Rineka Cipta.

Yusuf, Syamsu. 2006. Program Bimbingan dan Konseling di Sekolah (SLTP dan SLTA). Bandung: Pustaka Bani Quraisy.

Yusuf, Syamsu dan Nurihsan, Juntika. 2008. Landasan Bimbingan dan Konseling. Bandung: Remaja Rosdakarya.

Walgito, Bimo. 2005. Bimbingan dan Konseling (Studi dan Karir). Yogyakarta: Andi.

Winkel. 2006. Bimbingan dan Konseling di Institusi Pendidikan. Yogyakarta: Media Abadi. 